\title{
Spasmodic Torticollis - Review of 220 Patients
}

\author{
P. Rondot, M.P. Marchand and G. Dellatolas
}

\begin{abstract}
: 220 patients with isolated and idiopathic spasmodic torticollis were followed and treated over a 14 year period. Each patient was given a short questionnaire leading to the present retrospective data analysis. In most areas, including female preponderance and frequency of postural tremor, the findings confirmed previous studies and highlighted particular points: importance of psychopathological antecedents and association with stressful life-events. The discussion deals with some of the conflicting debates surrounding this unusual disorder. What is the role of psychopathological factors? What is the therapeutic prognosis? The best therapeutic results were obtained by combining anticholinergic drugs, local injections and rehabilitation.
\end{abstract}

RÉSUMÉ: En 14 ans, 220 patients ont été suivis et traités pour un torticolis spasmodique isolé et idiopathique. Pour chacun de ces sujets, un questionnaire d'évaluation abrégé a été rempli. La prise en compte des données ainsi rassemblées a conduit à la présente étude rétrospective. Dans la plupart des domaines les résultats confirment les études antérieures; ils mettent aussi en lumière des points particuliers: importance des antécédents psychopathologiques, association à des événements vitaux stressants. La discussion aborde certaines controverses suscitées par cette dystonie: quel est le rôle des aspects psychopathologiques? Quelles sont les perspectives thérapeutiques? Les meilleurs résultats dans ce domaine ont été obtenus en associant anticholinergiques, injections locales et rééducation.

Can. J. Neurol.Sci. 1991; 18: 143-151

In 1940, Kinnier Wilson stated "torticollis is a mere symptom and self-evident at that". 1 This symptom can be described as an abnormal involuntary contraction of muscles of the neck resulting in sustained movements or abnormal postures of the head. ${ }^{2}$ The chin may be turned to one side or the other (torticollis) and the head may be tilted to one side (laterocollis), pushed forward (antecollis) or even thrown backwards (retrocollis). ${ }^{3}$ This clinical description remains the only noncontroversial point in one of the most ambiguous areas of the neuropsychiatric literature. 2

This problem dates from the most distant past since this abnormal position has been described in fossil dinosaurs ${ }^{4}$, and Rabelais coined the word "torty colly" to describe how one of his characters, Epistemon, was beheaded and underwent a head transplant by Panurge..$^{5}$ A century later, in 1641 , a German military surgeon, Isaac Minnius, is said to have experimented with treatment by myotomy. ${ }^{6}$

Theoretical debates arose in the 19th century. By questioning whether torticollis was an organic or a functional disorder, Brissaud stated the problem in terms relevant to the controversy today. He contrasted "spasms as mere phenomena originating in the spine, which are uniquely reflexes" with "tics, coordinated phenomena, originating in the cortex, which are automatisms."
He placed torticollis in the tic category. "Mental torticollis" became part of medical terminology when in 1902 Meige wrote "the morbid condition is not to be found either in the muscles or in the nerves but in the mind itself." 8 Babinski took the opposite point of view and identified neurological symptoms associated with Spasmodic Torticollis (ST). ${ }^{9}$ Cruchet also disagreed: he studied eight types of torticollis and found only one which he could classify in the so-called mental category. ${ }^{10}$ Barré considered the disorder organic but at the same time mentioned a neurotic basis. 11

Later works favoured the organic nature of the affection without going so far as to offer irrefutable proof. Focal lesions in parts of the subcortex induce abnormal cervical postures in laboratory animals ${ }^{12.17}$, but extrapolating from animal models to humans with ST has not led to certain conclusions.5.18 In the few available postmortem studies, it was not possible to identify cerebral lesions. ${ }^{19-21}$ Work based on paraclinical examinations has similarly provided only limited proof of the organic origin of ST; a hypothesis which stated that the disorder could arise from abnormal labyrinthine function ${ }^{22}$ was not confirmed. ${ }^{23}$

The best-documented contemporary organic approach describes the genesis of ST as "a perturbation in the extrapyramidal system." 2 Two sets of data support this hypothesis 24 :

From the Service de Neurologie, Centre Hospitalier Sainte Anne, Paris, France

Received November 28, 1989. Accepted in final form October 24, 1990

Reprint requests to: Dr. P. Rondot, Centre Raymond Garcin - Service de Neurologie, Centre Hospitalier Sainte Anne, 1, rue Cabanis - 75674 Paris Cedex 14 - France 
symptomatic ST noted in conditions such as encephalitis lethargica which affects the basal ganglia and iatrogenic ST caused by long-term neuroleptic treatment ${ }^{25,26}$ and to a lesser degree by levodopa. 27,28

In turn, the extrapyramidal model of ST has sparked a controversy which is no longer etiological but nosological. Torticollis frequently appears in the autosomal dominant form of torsion dystonia. Eldridge studied 44 such patients and recorded that $51 \%$ suffered from torticollis. ${ }^{29}$ In $20 \%$ of these cases torticollis was the initial sign. Some researchers insist that basic types of slowly evolving oligosymptomatic torsion dystonia spasms do exist. ${ }^{30}$ Others reported that ST sometimes developed as an extension of dystonia. ${ }^{30.31}$ Marsden and Harrison have described sporadic, late-developing torsion spasms with a favourable prognosis; however in these adult forms they did not include isolated cases of ST. ${ }^{32,33}$

Such a combination of conflicting data tends to diminish the distinction between ST and dystonia musculorum deformans. Opposing views have generated the lively controversy we know today and we wonder as Couch stated whether "ST is a form fruste of DMD or an independent entity." 34 Herz and Glazer ${ }^{35}$, Eldridge ${ }^{29}$, Marsden 24,36 and Fahn ${ }^{37}$ all agree with Lee ${ }^{38}$ that "ST is the most common form of idopathic torsion dystonia." Others have refused to confuse working hypotheses with factual postulates and, on the basis of clinical practice, have made a clear distinction between the two syndromes. 5.30 Some workers go beyond merely emphasizing the ST/DMD distinction: they argue that the absence of dystonic signs elsewhere in the body should be included in the very definition of ST. 39.40

In the present paper, our goal was to compare our findings with previously published studies. ${ }^{3,6,31,41}$ It is difficult to study large series because we are dealing with a relatively rare disorder whose prevalence and incidence are unknown. ${ }^{42}$

\section{Material and Methods}

During the period between 1972 and 1986,220 patients were examined, followed and treated as cases of isolated and idiopathic spasmodic torticollis as previously defined.3,31 Cases of ST associated with abnormal cervical, spinal or muscular anatomy were excluded. Also excluded were cases of ST in generalized torsion dystonia or associated with tardive dyskinesia.

In this retrospective study, each of the 220 cases was documented by a questionnaire specifically developed for the study and completed by two of the authors (P.R., M.P.M.). The information was obtained by checking the hospital records on all patients. When some details were unclear or lacking, more precise information was obtained as often as possible during a follow-up contact. Twenty-one patients were excluded because of insufficient information.

Besides a demographic information section, the questionnaire included detailed questions regarding features of onset, clinical characteristics, antecedents, social consequences, course of the disease and treatments. Data concerning clinical course was categorized under three chronological headings: the date of onset and the dates of the first and last consultations. A chronological natural history was not feasible. Electromyographic data was considered to be outside the scope of this study.

\section{RESULTS}

\section{Sex Ratio and Age of Onset (Table 1, Figure 1)}

In this series, men and women are not equally affected: 76 (32.8\%) of our 199 patients were male and 123 (62\%) were female; the ratio was 1.0 to 1.6 . Thus, the female preponderance in this material is significant $(\mathrm{p}<0.05)$. Figure 1 shows the age at onset of ST in 195 subjects, with the mean age at 42 years.

The results collected by different researchers in the areas of sex ratio are conflicting: a greater frequency in men than in women 2.31 , a sex-ratio $1.1^{40,43,44}$ and a female preponderance. ${ }^{23,41,45,65}$ Recently, Duane ${ }^{46}$ found that females outnumbered males 1.6: 1.0, a ratio identical to our own.

The possible female preponderance of ST sufferers, the fluctuations in intensity noted in dystonia and the recently recognized role of estrogens in dyskinetic disorders 47,48 bring into focus the same questions about the monthly modulations of dystonia in female ST as exist for Parkinson's disease. ${ }^{49}$

The average age at onset in all studies is remarkable identical: Hamby and Schiffer ${ }^{50}$ set the median at 40 years, Rondot ${ }^{5}$ in a previous series, placed the average between 41 and 45 years. Tsui ${ }^{51}$ notes an onset mean of 41.9 years, Jayne 5241.7 years, Cockburn 5339.7 years.

\section{Hand Preference (Table 1)}

Eighty-nine percent of the patients studied were right-handed: $7 \%$ were ambidextrous and $4 \%$ were left-handed, the $11 \%$ of non right-handedness corresponding to the frequency expected in comparison with the general population.

\section{Extrapyramidal Antecedents (Table 1)}

$38.5 \%$ of patients noted extrapyramidal symptoms before the onset of ST. The most frequent was postural tremor (21\%). Twelve patients $(6.5 \%)$ who at first had writer's cramp, later developed ST. ST occurred in conjunction with blepharospasm in 3 patients. The association of ST and Parkinson's disease appeared in one patient.

Amongst the 151 patients systematically questioned about extrapyramidal disorder in their first degree relatives (parents, sibling or children), none reported symptomatology resembling blepharospasm or torsion dystonia amongst family members. Thirty-nine $(25.8 \%)$ noted the occurrence of other extrapyramidal features in the family, postural tremor in 21 cases and ST in 7.

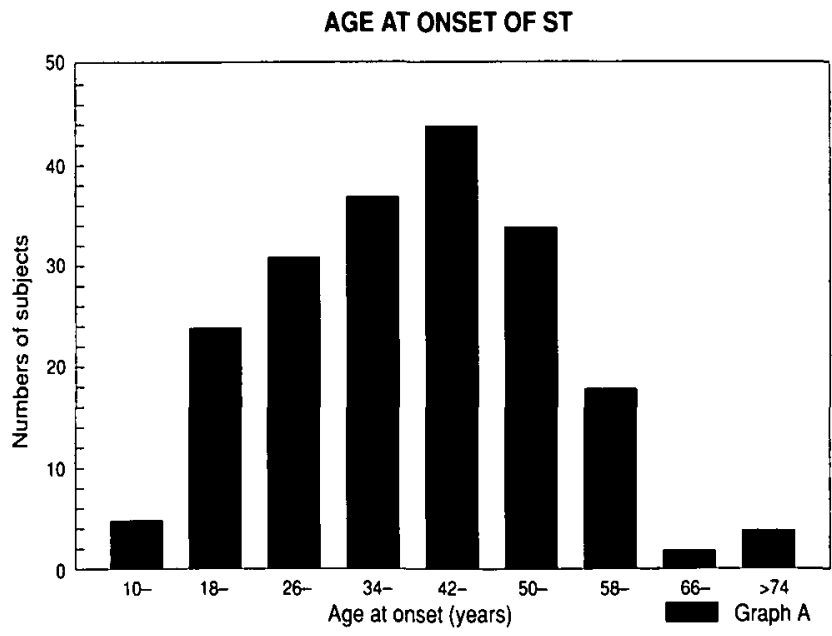

Figure I 
Marsden ${ }^{36}$ reported on the development of 5 cases of torticollis and 1 case of retrocollis within a group of 14 patients with dystonic writer's cramp. The rare association of Parkinson's disease with ST had already been described by Hernesniemi ${ }^{54}$ and others. 5,23 . The most important finding is the $21.1 \%$ frequency rate of ST in association with benign idiopathic of familial tremor. The earlier literature contains conflicting data concerning this association. Meares ${ }^{55}$ found it in one of 36 patients, Cooper $^{56}$ in $25 \%$ of cases. Couch ${ }^{34}$ recorded 26 cases of tremor in $30 \mathrm{ST}$ patients. The association of postural tremor with tor-

Table 1. Distribution of the Principal Characteristics in 199 Cases of ST

\begin{tabular}{lllr}
\hline \hline SEX & & MANUAL PREFERENCE \\
men & $: 38.2 \%$ & right-handed & $: 89 \%$ \\
women & $: 61.8 \%$ & left-handed & $: 4 \%$ \\
& & ambidextrous & $: 7 \%$
\end{tabular}

\section{ANTECEDENTS}

\begin{tabular}{|c|c|c|c|}
\hline Extrapyramidal per & $38.4 \%$ & & | $25.8 \%$ \\
\hline Tremor & $21.1 \%$ & & $14.6 \%$ \\
\hline Blepharospasm & $1.6 \%$ & & - \\
\hline Writer's cramp & $6.5 \%$ & & $1.3 \%$ \\
\hline Parkinson's disease & $0.5 \%$ & & $3.3 \%$ \\
\hline Tics & $8.7 \%$ & & $2 \%$ \\
\hline & Torsion & onia & \\
\hline
\end{tabular}

Thyroid disorder $2 \%$

Psychopathological personal Psychosomatic 19\%

minor $\quad 33 \%$

major $\quad 25 \%$

\section{SOCIAL CONSEQUENCES}

Mild : $43 \%$

Moderate : $40 \%$

Severe : $16 \%$

\section{Onset Mode of ST}

$\begin{array}{lllr}\text { Sudden } & 11 \% & \text { Two stages } & 6 \% \\ \text { Rapid progression } & 36 \% & \text { Onset pain } & 58 \% \\ \text { Slow progression } & 47 \% & \text { Initial head tremor } & 30 \%\end{array}$

\section{Factors Concomitant With ST Onset}

$\begin{array}{lcll}\text { Cranian traumatism } & 5 \% & \text { Work related events } & 9.5 \% \\ \text { Infection } & 1 \% & \text { Others } & 5.3 \% \\ \text { Neuroleptics administration } & 5 \% & \text { Several Factors } & 6.3 \% \\ \text { Emotional shock } & 29.1 \% & & \end{array}$

\section{Clinical Types}

$\begin{array}{llll}\text { Simple torticollis } & 36.6 \% & \text { Laterocollis } & 3.8 \% \\ \text { Laterotorticollis } & 21.9 \% & \text { Latero-retrocollis } & 3.3 \% \\ \text { Torticollis-Retrocollis } & 17.5 \% & \text { Retrocollis } & 1.1 \% \\ \text { Torticollis-laterocollis- } & & & \\ \text { Retrocollis } & 15.8 \% & & \end{array}$

\section{Supine Position or Head-Supported Position}

Improved : $48 \% \quad$ Worsened : $28 \% \quad$ No effect : $24 \%$

\author{
Correcting Counter-Movement $\quad 78 \%$
}

Writing Difficulties and/or Impaired Dexterity $\quad 48 \%$ sion dystonia has been widely recognized.32.57.58.59 Elsewhere, the existence of several patients $(4.6 \%)$ with familial ST must be emphasized. Isolated observations of familial ST have already been recorded by Thompson 60 , Van Bogaert ${ }^{61}$, Gilbert ${ }^{62}$ and others. $3,6,10,25,30$

\section{Psychopathological and Psychosomatic Antecedents (Table 1)}

The evaluation of psychological antecedents was based primarily on information provided by the patients themselves and, secondarily, on observations of the clinician. The presence or absence of previous psychological disorders and their character - moderate or severe - were the main data taken into account.

Moderate disorders consisted mainly of anxiety and were almost exclusively character traits rather than anxiety states as proposed by Spielberger. ${ }^{63}$ Also included amongst moderate disorders were cyclothymia, dysthymia, somatoform disorders and the most obvious personality disorders when they led to interpersonal problems. Major antecedents included schizophrenia and other psychotic conditions, bipolar disorders, major depressions and any disorder leading to psychiatric hospitalization. Antecedent psychological disorders were noted in $58 \%$ of our cases, $33 \%$ were moderate, $25 \%$ major. The extreme sensitivity of ST to mental stress was repeatedly emphasized by almost all patients $(94 \%)$. The same was true for social stress in most cases although 13 patients felt that social activity distracted them from their disorder providing temporary relief. These observations on psychologic disorders associated with ST cannot readily be correlated with previous reports in the literature which are generally conflicting and non-informative on this topic. Several authors 64.68 have attributed various symbolic meanings to ST and have viewed the twisting neck as a defence mechanism against psychological conflicts.

No conclusion can be drawn from these earlier psychoanalytic theories which lack objectivity and are based on few examples. More recent studies with apparently sounder experimental bases are in conflict. Paterson 69 found $80 \%$ of his patients to have abnormal personalities, Herz and Glaser ${ }^{35} 63 \%$. Podivinsky ${ }^{2}$ describes an abnormal personality profile in, at least, $50 \%$ of cases. Meares ${ }^{55}$ and Tibbets $^{6}$ suggested that an underlying psychiatric illness might exist in patients with ST while Cockburn 53 , Choppy-Jacolin et al70, Jahanshahi and Marsden 71 and Naber et al ${ }^{72}$ found no significant differences between dystonic patients and control groups. Our own results in this field must be interpreted cautiously because the retrospective nature of the study did not allow comparison with observations on matched controls. However, if we consider the type of disorders within the group having psychological antecedents, the high incidence of anxiety (anxious disorders as well as anxious-fearful personalities) in contrast to the rarity of affective or somatoform antecedents is worth noting. In 19\% of cases, diseases often considered to have a psychosomatic component (asthma, peptic ulcer, hemorrhagic rectocolitis, certain dermatoses, tension headache, palpitations) were found to have been present previously or concomitant with ST. Antecedent thyroid disorders were rare; an association appeared in only 4 cases. Our results agree with those of Matthew's ${ }^{23}$ and conflict with Gilbert ${ }^{73}$ and Duane ${ }^{46}$ who found an association between thyroid disorders and ST. 


\section{Social Consequences (Table 1)}

Social consequences of dystonia were analyzed in a four-tier classification: absent, mild (subjective feeling of discomfort in social conditions without objective consequences on social life), moderate (subjective feeling of discomfort leading to a modification of the qualitative aspects of social life but without lessening of the occupational level), severe (both qualitative and quantitative modification of the occupational level with resulting impairment of social life). The evaluation, resulting from a comparison between the patient's own appreciation and the physician's estimate of the subject's social life detected social consequences in $99 \%$ of cases. They were considered mild in $40 \%$, moderate in $42 \%$, and severe in $17 \%$. For the same grade of severity, there was a wide difference in perception of social consequences amongst different subjects. Amongst 3 rd grade patients ( $59 \%$ of the total), $43 \%$ considered social consequences of their disorder mild, $40 \%$ moderate, $16 \%$ severe. In 2 nd grade patients, social consequences were declared mild by $55 \%$, moderate by $41 \%$, severe by $8 \%$. Thus the previous assertion of ST being a socially crippling disorder ${ }^{36}$ does not seem to be confirmed by the present study. In $83 \%$ of subjects, social consequences did not exceed moderate severity. Furthermore, the appreciation of social consequences is highly subjective and reflects the individual variations in the relationship between the disorder and the personality dealing with it.

\section{Onset Mode and Severity (Tables 1, 2)}

The mode of onset was sudden in $11 \%$ of patients and progressive in $83 \%$. The onset in 11 patients $(6 \%)$ was in 2 stages, sometimes many years apart. This onset in 2 stages may correspond to spontaneous or non-spontaneous remissions described by several authors. ${ }^{74,75,52,41}$ Lowenstein and Aminoff 76 followed 24 patients with ST, $3(13 \%)$ underwent complete or almost complete remission at a median of 3 years into the illness while $8(33 \%)$ had partial remissions. More recently, Johanshahi et al ${ }^{77}$, studying 72 patients, found that 15 (20.8\%) had experienced a spontaneous remission of their ST, sustained for a median period of 3 years in 9 cases $(12.5 \%)$.

In $58 \%$ of our cases, ST onset was accompanied by pains in the neck, sometimes extending into the shoulders and back

Table 2: The Severity of Spasmodic Torticollis at the First Consultation

Grade 1: Intermittent lateral movements within the normal range of neck movements

Grade 2: Intermittent lateral movements interrupted by short tonic deviations which allow voluntary movement

Grade 3: Permanent tonic deviation of the neck which can be momentarily corrected at will

Grade 4: Permanent tonic deviation that cannot be corrected by voluntary movements but can be restrained by a countermovement

Grade 5: Permanent deviation unrestrainable by either voluntary movements or correcting countermovements

$10 \%$
(5\%). In approximately one-third of patients (34\%), initial head tremor was recorded. A similar incidence of head tremor has already been reported by Barrél1 in 1929. These are not clonic movements but rather postural tremors, often of a negative type. Head twisting lessens or abolishes the tremor. ${ }^{5}$ Thus, ST may appear initially as a palliative attempt to calm the tremor.

From the first consultation, ST severity was assessed by a 5 stage clinical measurement as defined by Rondot. ${ }^{78}$ The majority of patients $(59 \%)$ were as stage 3 . There was no significant correlation between the initial gravity of ST and personal (or familial) extrapyramidal antecedents.

\section{Factors Concomitant With Onset (Table 1)}

A majority of patients (61\%) suggested different events which they held responsible for the onset of ST. These factors ranked according to frequency were: emotional shock relating to a family incident (marital disputes, separation, divorce, conflicts with children, births, deaths) or medical problems (pregnancies, hysterectomies), professional upsets (layoffs, unemployment, transfers, financial worries, exam failures), motor vehicle accidents resulting in head trauma, a neuroleptic prescription (even in moderate doses), a febrile illness (viral or bacterial infection). Eleven patients mentioned other situations, particularly stereotyped, repetitive and unidirectional work gestures recalling the "occupational torticollis" already mentioned. ${ }^{5,69}$ In the case of 13 patients, several situations were combined.

The small group of subjects to whom neuroleptics had been administered prior to the onset of ST is considered separately. With respect to their characteristics no difference from other ST cases was detected; the similarity between extrapyramidal syndromes induced by antipsychotic medication and abnormal spontaneous onset of movements has already been emphasized. ${ }^{79}$ Some authors 80,81 contend that amongst patients with neuroleptic-induced ST, chronic and acute cases differ, the first group corresponding to tardive dyskinesias. The favourable effects of anticholinergics on both ST groups ${ }^{82}$ and their ineffectiveness in neuroleptic tardive dyskinesia lead us to question the validity of this separation.

The most puzzling point is the high rate of self-reported stress factors before the onset of the movement disorder and the frequency with which patients establish a causal relationship. A review of the contemporary literature leaves the reader confused. Choppy-Jacolin et $\mathrm{al}^{70}$ and Matthews et al ${ }^{23}$ documented stressful life-events and speculated that they precipitated the onset of ST. Jahanshahi and Marsden ${ }^{71}$ compared 100 ST patients and a control group of 49 patients with cervical spondylosis with regard to different features, particularly events preceding onset of their complaint; they found no significant differences between the two groups. A majority (64\%) of patients in the ST group, a proportion similar to that of the present sample, reported various events prior to the onset of their disorder. The corresponding proportion in cervical spondylosis group was $45 \%$. More specifically, the identical proportion of physical events $(26 \%)$ in the two groups refuted the specificity of their role in the onset of ST. In a more recent study ${ }^{83}$ a role of trauma was proposed for the development of dystonic states at least in a genetically predisposed population. Previously, Korein et al ${ }^{84}$ used the same issue without drawing conclusions.

Finally, interesting findings could be observed but, for the moment, the high rate of stress factors concomitant with onset 
can only be mentioned without interpretation. The variable impact of the same incident on different individuals requires rigorous, reliable and well documented life-event methodology and entails a need for multi-directional evaluation that consider individual sensitivities by several observers. 85

\section{Clinical Types, Countermovement, Role of Headsupport,} Lying and Sleeping (Table 1)

Torticollis itself was present in $91.8 \%$ of cases, either isolated $(36.6 \%)$ or, more often, associated with laterocollis and, or retrocollis $(52.2 \%)$. The lateral turning or leaning of the head was reported to the right side as often as the left, independent of handedness. Some researchers ${ }^{86}$ cite predominantly left turning without proving statistical significance.

Whatever the clinical type, the rate of compensating countermovement is high $(78 \%)$. The movements accompanying ST (geste paradoxal) occurred in $22 \%$ of our cases and was particularly frequent in the clinical association of torticollis, laterocollis and retrocollis; Stejskal ${ }^{87}$ had previously noticed that it was more frequent when the head tilted rather than twisted.

The result of reclining or headsupport was described by 120 patients: $48 \%$ improved in a reclining position; $28 \%$ worsened. Of the 63 patients for whom information about sleep was available, 4 cases $(5 \%)$ revealed the persistence of abnormal movements while sleeping. Several studies, indeed, report that at least the clinical symptoms of ST disappear during sleep. ${ }^{5,78}$ But, in 1980 , EMG trials revealed that the 13 subjects in the ST group recorded the same cervical muscle activity during sleep as in the waking state while in the 13 control group cases, almost no activity during sleep was recorded..$^{5}$ Forgach et al ${ }^{88}$ confirmed these preliminary data.

\section{Writing Difficulties and/or Impaired Dexterity (Table 1)}

Almost half $(48 \%)$ of the ST patients complained of various degrees of difficulty in writing or impaired dexterity. Though we could not use objective evidence by dystonic scores ${ }^{34}$, these findings probably confirm the observation of numerous researchers $2,3,31,34,35$ that ST dystonia is not limited to the cervical region.

\section{Clinical Course and Prognostic Indicators (Table 3)}

Although the duration of care varied greatly between subjects, it was long enough to allow classification of the course of ST in 167 patients in 5 grades. Table 3 outlines certain prognostic trends; the variables indicated did not, however, constitute reliable prognostic indicators because these differences were not significant enough to reach the 0.05 threshold. More particularly, neither the subject's ages, nor the duration of ST appeared to influence the prognosis of the disorder.

Other researchers ${ }^{77}$ presented the natural history of 72 patients with adult onset torticollis followed for a mean of 7.7 years; they found that the 15 cases with spontaneous remission tended to have an earlier age of onset compared with those without remission. Age at onset was the only salient variable in the discrimination of patients with and without spontaneous remission. However, because of the high classification error rate $(35 \%)$, this variable was not considered a reliable prognostic indicator for future samples of ST patients.

\section{Discussion}

\section{Psychological Factors Affecting ST}

The results of new studies are regularly challenged by contradictory reproaches: either they add no new material to current knowledge of the condition being studied or they depart from generally accepted concepts.

In the present study, any suggestion that the rehabilitation of psychological factors is involved in ST is open to scathing criticism. Contemporary thought, neurological as well as psychiatric, considers the matter more in an historical fashion, now outdated, than as a serious topic. How then could the most recent works on the subject contradict the established postulate of a "somatic origin" of ST? Indeed they do not.

Two main models disqualify any attempt at a psychological approach. The first states that ST is such a socially crippling and disabling condition that people are necessarily stressed, depressed or in some cases could even modify their personality

Table 3: Outcome According to Subject and Disorder's Main Characters

\begin{tabular}{|c|c|c|c|c|c|}
\hline & $0^{\star}$ & $1^{*}$ & $2^{*}$ & $3^{*}$ & $4^{*}$ \\
\hline Subject Total & 10.2 & 8.4 & 37.1 & 29.3 & 15.0 \\
\hline \multicolumn{6}{|l|}{ Sex } \\
\hline $\begin{array}{l}\text { Men } \\
\text { Women }\end{array}$ & $\begin{array}{r}7.8 \\
11.6\end{array}$ & $\begin{array}{l}9.4 \\
7.8\end{array}$ & $\begin{array}{l}39.1 \\
35.9\end{array}$ & $\begin{array}{l}31.2 \\
28.2\end{array}$ & $\begin{array}{l}12.5 \\
16.5\end{array}$ \\
\hline \multicolumn{6}{|c|}{ Extrapyramidal Family Antecedents } \\
\hline $\begin{array}{l}\text { Absent } \\
\text { Present }\end{array}$ & $\begin{array}{r}11.1 \\
7.3\end{array}$ & $\begin{array}{l}7.9 \\
9.8\end{array}$ & $\begin{array}{l}35.7 \\
41.5\end{array}$ & $\begin{array}{l}30.2 \\
26.8\end{array}$ & $\begin{array}{l}15.1 \\
14.6\end{array}$ \\
\hline \multicolumn{6}{|c|}{ Extrapyramidal Personal Antecedents } \\
\hline $\begin{array}{l}\text { Absent } \\
\text { Present }\end{array}$ & $\begin{array}{r}8.3 \\
13.8\end{array}$ & $\begin{array}{l}8.3 \\
8.5\end{array}$ & $\begin{array}{l}33.9 \\
43.1\end{array}$ & $\begin{array}{l}33.9 \\
20.7\end{array}$ & $\begin{array}{l}15.6 \\
13.8\end{array}$ \\
\hline \multicolumn{6}{|c|}{ Psychopathological Signs } \\
\hline $\begin{array}{l}\text { Absent } \\
\text { Minor } \\
\text { Major }\end{array}$ & $\begin{array}{r}12.3 \\
3.4 \\
16.3\end{array}$ & $\begin{array}{r}7.7 \\
6.8 \\
11.6\end{array}$ & $\begin{array}{l}33.8 \\
39.0 \\
39.5\end{array}$ & $\begin{array}{l}27.7 \\
37.3 \\
20.9\end{array}$ & $\begin{array}{l}18.5 \\
13.6 \\
11.6\end{array}$ \\
\hline \multicolumn{6}{|c|}{ Factors Concomitant with ST Onset } \\
\hline $\begin{array}{l}\text { Absent } \\
\text { Present }\end{array}$ & $\begin{array}{r}8.5 \\
11.1\end{array}$ & $\begin{array}{r}13.6 \\
5.6\end{array}$ & $\begin{array}{l}30.5 \\
40.7\end{array}$ & $\begin{array}{l}28.8 \\
29.6\end{array}$ & $\begin{array}{l}18.6 \\
13.0\end{array}$ \\
\hline \multicolumn{6}{|l|}{ Onset Mode } \\
\hline Sudden & 7.1 & 0.0 & 42.9 & 50.0 & 0.0 \\
\hline $\begin{array}{l}\text { Rapid progression } \\
\text { Slow progression }\end{array}$ & $\begin{array}{l}8.6 \\
7.9\end{array}$ & $\begin{array}{r}10.3 \\
7.9\end{array}$ & $\begin{array}{l}32.8 \\
42.9\end{array}$ & $\begin{array}{l}29.3 \\
31.8\end{array}$ & $\begin{array}{r}19.0 \\
9.5\end{array}$ \\
\hline Two-stage & 30.0 & 0.0 & 30.0 & 20.0 & 20.0 \\
\hline \multicolumn{6}{|l|}{ ST Grades } \\
\hline Grade 1 and 2 & 5.4 & 2.7 & 51.3 & 18.9 & 18.9 \\
\hline Grade 3 & 10.6 & 6.4 & 36.2 & 30.8 & 15.0 \\
\hline Grade 4 and 5 & 14.7 & 17.6 & 23.5 & 38.2 & 3.0 \\
\hline \multicolumn{6}{|l|}{ Retrocollis } \\
\hline $\begin{array}{l}\text { Absent } \\
\text { Present }\end{array}$ & $\begin{array}{l}10.0 \\
10.5\end{array}$ & $\begin{array}{l}9.0 \\
8.8\end{array}$ & $\begin{array}{l}30.0 \\
45.6\end{array}$ & $\begin{array}{l}34.0 \\
22.8\end{array}$ & $\begin{array}{l}17.0 \\
12.3\end{array}$ \\
\hline $\begin{aligned}{ }^{*} 0 & \text { No improvement } \\
2 & \text { Partial improveme } \\
4 & \text { Clinical cure }\end{aligned}$ & & $\begin{array}{l}\text { Doul } \\
\text { Majo }\end{array}$ & $\begin{array}{l}\text { imprc } \\
\text { prove }\end{array}$ & & \\
\hline
\end{tabular}


traits. Ascertaining the significance of psychological factors under such stressful conditions becomes difficult or impossible. Usually what is observed is considered "consequences" and not "causes." The second model is supported by an implicit dualistic position in the tradition of parallelists like Leibniz whose dualism could not admit any causal relation between matter and spirit. 89 The proposition regarding the aetiology of ST then becomes an alternative that either ST is of psychogenic origin or the movement disorder is of organic origin. The two propositions are inconsistent, each term of the binomial excluding the other.

The results of the present study do not confirm the first hypothetical model. Most patients considered that their social and occupational life was not modified even if in their inner feelings they were uncomfortable. The gap between subjective and objective fields is often found in ST, the differences playing in the two directions. In social life, subjective feelings are worse than objective consequences but in the controlled trial of botulinum toxin injections by Gelb et al, some patients showing objective deterioration nonetheless reported subjective improvement. 90

By contrast with the findings of Duane 46 , we did not find more evidence of frequent depression in response to the disorder. Patients knew that the dystonic movement would not spread and that their life was not threatened. Two negative features confirm that depression probably is no more than a mere epiphenomenon in ST: antidepressant treatments currently in use have not proved effective and the suicide ratio is low amongst this group ( $1 / 199$ in this series as an acting-out during a panicattack).

Let us now further examine the second model. Its philosophical connotation is surprising in medicine so far as "a division of intellectual labor has arisen in the West which accords to 'scientists' the task of establishing particular truths and to "philosophers' the role of making from those truths a coherent world." 89 But there is no antagonism between the two pursuits and that would not matter if the system chosen was not precisely the one denying the interaction of mind and body. If the modern neurological schools must be dualists, more fruitful work could be done if one referred to the common cartesian form of dualism, the one exemplified by the great modern neurophysiologist $\mathrm{Sir}$ John Eccles who accorded "spatial patterning" to the mind.

Finally we think that several psychological aspects surrounding ST could be underestimated and amongst them two observations deserve emphasis:

1. our empirical view based on a large population is that a strong link seems to exist between ST and anxiety. The word anxiety is used here in its most comprehensive meaning, including not only anxiety syndromes but also personality traits and disorders, corresponding for the latter to the cluster "anxiousfearful" of the DSM III R.91 It would be an important step to confirm or refute such a clinical appreciation by a rigourous study.

2. DSM III $\mathrm{R}^{91}$ proposed diagnostic criteria for a new category corresponding to disorders that in the past had been referred to as "psychosomatic" or "psychophysiological." It must be underlined that ST fulfills the 3 criteria of this category entitled "Physical condition affected by psychological factors": a) "Psychologically meaningful environmental stimuli are temporally related to the initiation or exacerbation of a specific physical condition or disorder." A temporal relationship is nearly always found between the onset of ST and psychosocial or physical events considered by the subjects to be psychologically meaningful. The extreme sensitivity of the disorder to social and mental stress also suggests that psychological factors could be contributory. b) "The physical condition involves either demonstrable organic pathology or a known pathophysiologic process." Paradoxically, with regard to the supporters of an exclusive organic origin to ST, criterion B is not yet unequivocally fulfilled. Clear pathoanatomical and/or biochemical findings or pathophysiologic understanding of the process are indeed still lacking. c) "The condition does not meet the criteria for a somatoform disorder." Criterion C was satisfied in every case of the present data. Though a conversion of factitious disorder could take the form of ST, it seems particularly infrequent. A study collecting data on 1,185 patients seen by the Dystonia Clinical Research Centre reported 21 patients having somatoform dystonia. ${ }^{92}$

In concluding this delicate controversy, we would like to ensure that no reader understand that we propose a psychogenic cause to ST. We merely think that mind is part of the body. If the alteration of a defined chain of physiological events in the CNS can lead to a single clinical picture, it does not mean that a single factor is responsible or, if multiple, that all of them are "organic" in the crude sense of the term. In the case of ST, the onset of the disorder can already be traced to different factors such as a neurological disorder (epidemic encephalitis), biochemical disturbances (neuroleptic treatments), or genetic predisposition. Who has proven that other circumstances such as personality types, stress reactions, anxiety disorders, hormonal environment, or biological clocks, are not equally involved, in isolation or in association, in the origin of the disease?

\section{Therapeutic Outlook (Table 4)}

The results of different treatments presented in this study can certainly be criticized so far as the approach was neither doubleblind nor controlled. However, the large number of cases studied provide epidemiological data. In addition, the benefits demonstrated for a drug regime in the carefully and supervised setting of a clinical trial cannot necessarily be assumed to be maintained under the less regimented circumstances of everyday clinical practice.

In condensing the results from 42 therapeutic trials concerning 148 patients followed between 1937 and 1978, Lal $^{42}$ denoted 64 patients $(42.24 \%$ ) who benefitted from medical treatment. In our series, if treatment proved to be ineffective in $18.6 \%$ of the 199 patients, $37.1 \%$ had partial improvement and $43.3 \%$ found major benefits.

Ninety-eight per cent of the patients were given medication, usually anticholinergic drugs. The anticholinergics used orally were: procyclidin, $15-20 \mathrm{mg} / \mathrm{d}$, trihexyphenidyl, $10-15 \mathrm{mg} / \mathrm{d}$ or benztropin, $8-10 \mathrm{mg} / \mathrm{d} ; 85 \%$ received simultaneous physiotherapy and $78.2 \%$ underwent alcohol injections into motor points of the most affected muscles.

The effect of anticholinergics in previous studies has met with varying appraisals; however, most researchers recognize their effectiveness: negligible effects were noted in the small trial carried out by Patterson and Little 3 ; improvement was recorded by Rondot et $\mathrm{al}^{5}$, Lal et al ${ }^{93}$, Tanner et al ${ }^{94}$, and Stahl and Berger. ${ }^{95}$ These results approached those found in cases of 
adult dystonia: intravenous injections gave Lang et al ${ }^{96}$ no results but Fahn 97 found high dosage oral treatment to be effective.

When the results of the medical treatment were unsatisfactory, alcohol was injected into muscles which had been determined by EMG to be responsible for the ST. ${ }^{5}$ One or two series of ten injections were deemed necessary. This type of infiltration does not induce pharyngeal paralysis but is less effective than infiltrations with botulinum toxin and is sometimes painful for several days. Therefore, the patients still affected were later treated by local injections of botulinum A toxin. $90,98.99$

Eighty-five per cent of the patients received physiotherapy. Therapy began with passive manual techniques. Once the cervical rachis has regained some of its responsiveness, treatment is continued with active cervical exercises in hospital or at home, under the guidance of a physiotherapist. Motor-activating electrical current is used to provide stimulation, and muscular feedback also plays a role in rehabilitation.

\begin{tabular}{cc} 
Table 4: Outcome According to Diverse Treatme \\
\hline \hline Medical treatment & $98 \%$ \\
Monotherapies ** & $26 \%$ \\
Bitherapies $^{* *}$ & $46 \%$ \\
Tritherapies $^{* *}$ & $26 \%$ \\
Physiotherapy & $85 \%$ \\
Alcohol injections & $78 \%$
\end{tabular}

Percentage distribution of the 5 lines of development according to the different types of therapeutics

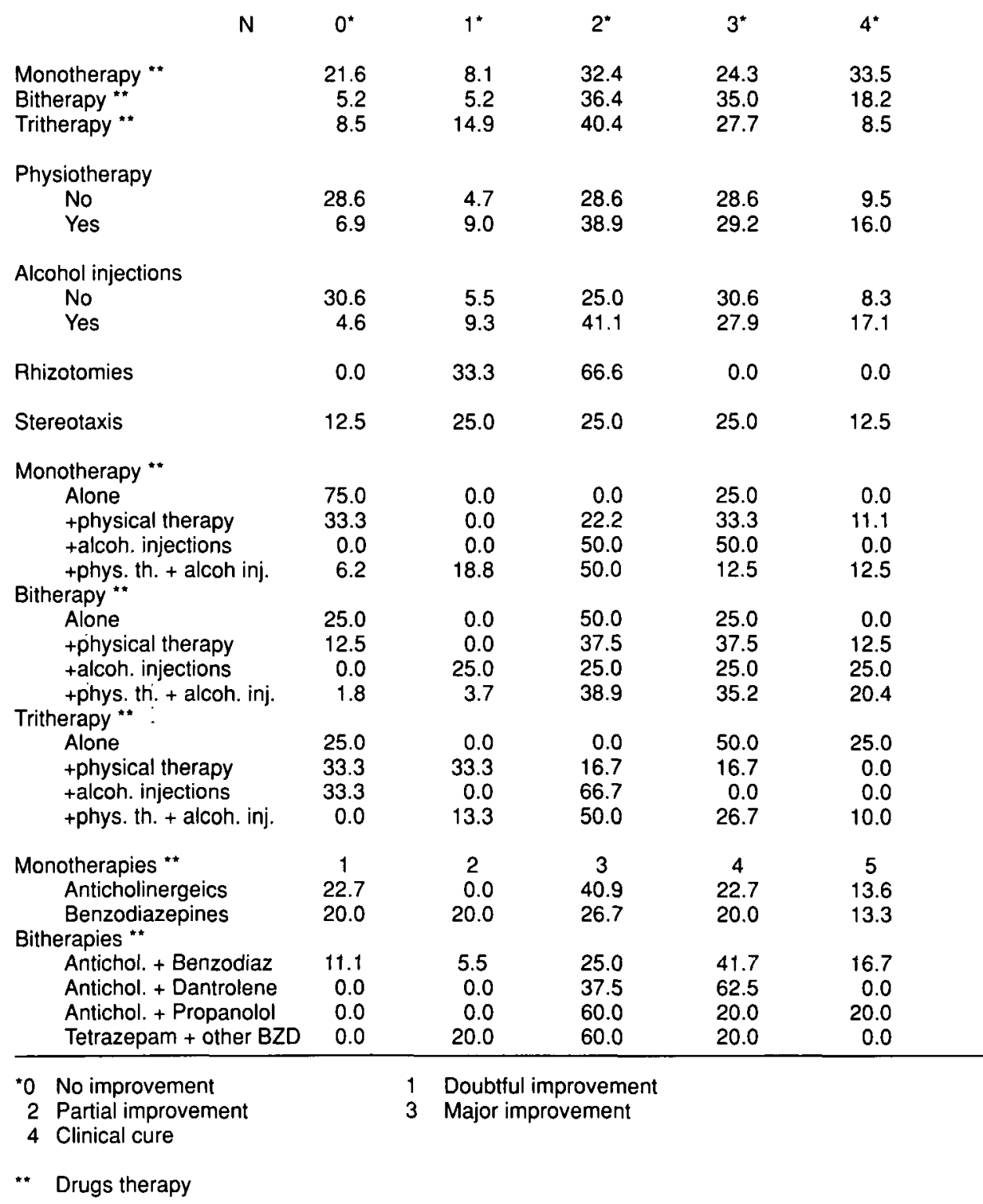




\section{Conclusion}

Kinnier Wilson described ST as a "mere symptom." However so many other factors are involved - the circumstances of its onset, its accompanying signs and the psychological profile of ST suffers - that we cannot consider it merely a symptom.

Are we dealing with a localized type of torsion dystonia? We might answer affirmatively if we refer to postural anomalies at the cervical level recorded in cases of generalized dystonia. But care must be taken not to consider it a "forme-fruste" of torsion dystonia. The age of onset for these two disorders is quite different. None of the antecedents reveal torsion dystonia.

Finally the question emerges whether we can clearly repudiate psychogenic mechanisms in the pathophysiology of ST. In our opinion, such a dismissal would be overly simplistic; we do not wish to go as far as Brissaud with his "mental torticollis" but we would like to emphasize that in the complex of factors leading to ST, psychological aspects do indeed play a role.

\section{REFERENCES}

1. Wilson SAK, In: Bruce AN, ed. Neurology. London: Arnold. 1940; 1664

2. Podivinsky F. Torticollis. In: Vinken PJ and Bruyn GW, eds. Handbook of Clinical Neurology. North Holland, Amsterdam. 1968; 567-603 (Diseases of the Basal Ganglia: vol. 16).

3. Patterson RM, Little SC. Spasmodic torticollis. J Nerv Ment Dis. 1943; 98: 571-599.

4. Martin PR. Spasmodic torticollis: A behavioural perspective. J Behav Med 1982; 5: 249-270.

5. Rondot P, Jedynak CP, Ferrey G. Le torticollis spasmodique. In: Masson, ed. Rapport de Neurologie. Congrès de Psychiatrie et Neurologie de Langue Française. Colmar: 1981.

6. Tibbetts RW. Spasmodic torticollis. J Psychosom Res 1971; 15: 461-469.

7. Brissaud E. Leçons sur les maladies nerveuses. Henry Meige. Paris 1895.

8. Meige H, Feindel E. Les tics et leur traitement. Masson, ed. Paris 1907.

9. Babinski J. Sur le spasme du cou. Rev Neurol (Paris) 1901; 693.

10. Cruchet R. Traité des torticolis spasmodiques, spasmes, tics, rythmies du cou, torticolis mental. Masson et Cie, 1907.

11. Barre JA. Le torticolis spasmodique. Rev Neurol (Paris) 1929; $984-$ 1013.

12. Kemberling SR, Baird HW, Spiegel EA. Experimental torticollis of rhomboencephalic origin. J Neuropath Exp Neurol 1952; 11: 184-191.

13. Carpenter MB. A study of the red nucleus in the rhesus monkey. Anatomical degeneration and physiological effects resulting from localized lesions of the red nucleus. J Comp Neurol 1956; 105: 195-249.

14. White RP. Hinwich HE. Circus movements and excitation of striatal and mesodiencephalic centers in rabbits. J Neurophysiol 1957; 20: 81-90.

15. Foltz EL, Knopp LM, Ward AA. Experimental spasmodic torticollis. J Neurosurg 1959; 16: 55-72.

16. Denny-Brown D. The midbrain and motor integration. Proc R Soc Med 1962; 55: 527-538.

17. Mizawa I. Experimental spasmodic torticollis in cat. Arch Jap Chirurg 1963; 32: 597-624.

18. Tarlov E. On the problem of pathology of spasmodic torticollis in man. J Neurol Neurosurg Psychiatry 1970; 33: 457-463.

19. Foerster O. Mobile spasm of the neck muscles and its pathological basis. J Comp Neurol 1933; 58: 725-735.

20. Grinker RR, Walker AE. The pathology of spasmodic torticollis with a note on respiratory failure from anaesthesia in chronic encephalitis. J Nerv Ment Dis 1933; 78: 630-637.

21. Alpers BJ, Drayer CS. The organic background of some cases of spasmodic torticollis. Report of a case with autopsy. Am J Med Sci 1937; 193: 378-384.

22. Svien HJ, Cody DTR. Treatment of spasmodic torticollis by suppression of labyrinthe activity: A report of a case. Mayo Clin Proc 1969; 44: 825-827.

23. Matthews WB, Beasley P, Parry-Jones W, Garland G. Spasmodic torticollis: A combined clinical study. J Neurol Neurosurg Psychiatry 1978; 41: 485-492.

24. Marsden CD. Dystonia: The spectrum of the disease. In: Yahr MD, ed. The basal ganglia. New York: Raven Press 1976; 35-67.

25. Chateau R, Fau R, Groslambert R, Perret J. A propos d'un cas de torticolis spasmodique irréversible survenu au cours d'un traitement par neuroleptiques. Rev Neurol (Paris) 1966; 144: 65-68.

26. Harenko A. Retrocollis as an irreversible late complication of neuroleptic medication. Acta Neurol Scand 1967; 43 (suppl. 31): 145-146.

27. Sigwald J, Raymondeaud C. Les mouvements anormaux observés au cours du traitement de la maladie de Parkinson par la $\mathrm{L}$. Dopa. Rev Neurol (Paris) 1970; 122: 103-112.

28. Barbeau A, Mars H, Gillojoffroy L. Adverse clinical side effects of levodopa therapy. In: McDowell $\mathrm{FH}$, Markham $\mathrm{CH}$, eds. Recent advances in Parkinson's disease. Philadelphia: FA Davis Co, 1971; 203-237.

29. Eldridge R. The torsion dystonias: Literature review and genetic and clinical studies. Neurology (Minneap) 1970; 20: 1-78

30. Zeman W, Dyken P. Dystonia musculorum deformans. In: Vinken PJ, Bruyn GW, eds. Handbook of clinical Neurology, NorthHolland. Amsterdam, 1968: 517-543 (Diseases of the basal ganglia: vol. 6).

31. Sorensen BF, Hamby WB. Spasmodic torticollis. Neurology 1966; 16: $867-878$

32. Marsden CD, Harrison MJG. Idiopathic torsion dystonia (dystonia musculorum deformans) Brain 1974; 97: 793-810.

33. Marsden CD, Harrison MJG, Bundey $S$. The natural history of idiopathic torsion dystonia. In: Eldridge $\mathrm{R}$, Fahn $\mathrm{S}$, eds. Advances in Neurology. New York: Raven Press 1976: 177-186 (Dystonia: vol. 14).

34. Couch JR. Dystonia and tremor in spasmodic torticollis. In: Eldridge R, Fahn S, eds. Advances in Neurology. New York: Raven Press 1976: 245-257 (Dystonia: vol. 14).

35. Herz E, Glaser GH. Spasmodic torticollis: Clinical evaluation. Arch Neurol 1949; 61: 227-239.

36. Marsden $C D$. The problem of adult-onset idiopathic torsion dystonia and other isolated dyskinesias in adult life (including blepharospasm, oromandibular dystonia, dystonic writer's cramp and torticollis or axial dystonia). In: Eldridge $\mathrm{R}$, Fahn S, eds. Advances in Neurology. New York: Raven Press 1976: 259-276 (Dystonia: vol. 14).

37. Fahn S, Eldridge R. Definition of dystonia and classification of dystonic states. In: Eldridge R, Fahn S, eds. Advances in Neurology. New York: Raven Press, 1976: 1-5 (Dystonia: vol. 14).

38. Lee MC. Spasmodic torticollis and other idiopathic torsion dystonias. Postgrad Med 1984; 75: 139-146.

39. Gildenberg PL. Comprehensive management of spasmodic torticollis. Appl Neurophysiol 1981; 44: 233-243.

40. Jorgensen C, Porphyris H. Idiopathic spasmodic torticollis. J Neurosurg Nurs 1985; 17: 169-174.

41. Friedman A, Fahn S. Spontaneous remissions in spasmodic torticolis. Neurology (Cleveland) 1986; 36: 398-400.

42. Lal S. Pathophysiology and pharmacotherapy of spasmodic torticollis. A review. Can J Neurol Sci 1979; 6: 427-435.

43. Lundberg NG, Svantesson G. The surgical treatment of dystonic torticollis. Acta Orthop Scand 1962; 32: 101-120.

44. Lishman WA. Spasmodic torticollis. In: Organic Psychiatry. Oxford, Blackwell Scientific Publications 1978; 776-784.

45. Klassen AC. Torticollis. Postgrad Med 1984; 75: 124-125.

46. Duane DD. Spasmodic torticollis: Clinical and Biologic Features and their implications for Focal Dystonia. In: Fahn S, et al, eds. Advances in Neurology. New York: Raven Press 1988: 473-492 (Dystonia 2: vol. 50)

47. Koller WC, Barr A, Biary N. Estrogen treatment of dystonic disorders. Neurology (NY) 1982; 32: 547-549. 
48. Robinson RO. Stutchfield P, Hicks B, Marsden CD. Estrogens and dyskinesia. Neurology (Cleveland) 1984; 34: 404

49. Quinn NP, Marsden CD. Menstral related fluctuations in Parkinson's disease. Movement Disorders 1986; 1: 85-87.

50. Hamby WB, Schiffer S. Spasmodic torticollis: Results after cervical rhizotomy in 50 cases. J Neurosurg 1969; 31: 323-326.

51. Tsui JK, Eisen A, Mak E, Larruthers J. Scott A, Calne DB. A pilot study on the use of botulinum toxin in TS. Can J Neurol Sci 1985; 12: 314-318.

52. Jayne D, Lees A, Stern GM. Remission in spasmodic torticollis. J Neurol Neurosurg Psychiatry 1984; 47: 1236-1237.

53. Cockburn TT. Spasmodic torticollis: A psychogenic condition? J Psychosomat Res 1971; 15: 471-477.

54. Hernesniemi J, Laitinen L. Resulats tardifs de la chirurgie dans le TS. Neurochirurgie 1977; 23: 123-131.

55. Meares R. Features which distinguish groups of spasmodic torticollis. J Psychosom Res 1971; 15: 1-11.

56. Cooper IS. Effect of thalamic lesions upon torticollis. N Engl J Med 1964; 270: 967-972.

57. Larsson T, Sjogren T. Dystonia musculorum deformans. A genetic and clinical population. Study of 121 cases. Acta Neurol Scand (suppl. 17) 1966: 1-232.

58. Johnson W, Schwartz G, Barbeau A. Studies on dystonia musculorum deformans.. Arch Neurol 1962; 7: 301-313.

59. Yanagisawa N, Goto A, Narabayashi $\mathrm{H}$. Familial dystonia musculorum deformans and tremor. J Neurol Sci 1971; 16: 125-136.

60. Thompson JH. A wry-necked family. Lancet 1896;2: 24 .

61. Van Bogaert L. Etudes anatomo-cliniques de syndromes hypercinétiques complexes. II. Un torticolis héréditaire et familial avec tremblement. Mschr Psychiat Neurol 1941; 103: $321-342$.

62. Gilbert GJ. Familial spasmodic torticollis. Neurology (Minneap) 1977; 27: 11-13.

63. Spielberger CD, Gorsuch RL, Lushene RE. Manual for the StateTrait Anxiety Inventory. Palo Alto, California: Consulting Psychologist Press, 1970

64. Ferenczi S. Le développement du sens de réalités et ses stades (Ed. Française) In: Psychanalyse tome 2; Payot Ed 1970; 51-65.

65. Whiles WH. Treatment of spasmodic torticollis by psychotherapy. Br Med J 1940; 1: 969-971.

66. Cleveland SE. Personality dynamics in torticollis. J Nerv Ment Dis 1961; 129: 150-161.

67. Abse DW. Hysteria and related disorders. Bristol: Wright, 1966.

68. Mitscherlich M. Spasmodic torticollis. Psychoter Psychosom 1971; 19: 62-75.

69. Paterson MT. Spasmodic torticollis: Results of psychotheraphy in 21 cases. Lancet $1945 ; 21: 556-559$.

70. Choppy-Jacolin M, Ferrey G, Demaria CA. A psychometric study of 34 patients afflicted with spasmodic torticollis and dystonia. Acta Neurol Scand 1977; 55: 483-492.

71. Jahanshahi $M$, Marsden $C D$. Personality in torticollis: A controlled study. Psychol Med, 1988; 18: 375-387.

72. Naber $D$, Weinberger DR, Bullinger $M$, et al. Personality variables, neurological and psychopathological symptoms in patients suffering from spasmodic torticollis. Comprehensive Psychiatry 1988; 29: 182-187.

73. Gilbert GJ. Spasmodic torticollis treated effectively by medical means. N Eng J Med 1971; 284: 896-898.

74. Lang AE, Marsden CD. Alphamethylparatyrosine and tetrabenazine in movement disorders. Clin Neuropharmacol 1982; 5: 375-387.

75. Meares R. Natural history of spasmodic torticollis and effect of surgery. Lancet $1971 ; 2: 149-151$.

76. Lowenstein DH, Aminoff MJ. The clinical course of spasmodic torticollis. Neurology 1988; 38: 530-532.

77. Jahanshahi $M$, Marion $M H$, Marsden $C D$. Natural history of adultonset idiopathic torticollis. Arch Neurol 1990; 47: 548-552.
78. Rondot $\mathrm{P}$, Bathien N, Ziegler $\mathrm{M}$. Les mouvements anormaux. Masson, ed. Paris 1988.

79. Marsden CD, Tarsy D, Baldessarini RJ. Spontaneous and druginduced movement disorders in psychotic patients. In: Benson DF, Blumer D, eds. Psychiatric aspects of neurologic disease. New York: Grune and Stratton 1975; 219-266.

80. Gupta JM, Lovejoy FM. Acute phenothiazine toxicity in childhood: A five-year survey. Pediatics 1967; 39: 771-774.

81. Swett C. Drug-induced dystonia. Am J Psychiatry 1975; 132: 532534.

82. DI Mascia A, Bernado DL, Greenblatt DJ, et al. A controlled trial of amantadine in drug-induced extra-pyramidal disorders. Arch Gen Psychiatry 1976; 33: 599-602.

83. Fletcher NA, Harding AE, Marsden CD. The role of trauma in the development of idiopathic torsion dystonia. J Neurol 1990; 237, (suppl.1): S5.

84. Korein J. Brudny J. Grynbaum B, Sachs-Frankel G, Weisinger M, Levidow L. Sensory feedback therapy of spasmodic torticollis and dystonia. Results in treatment of 59 patients. $\ln$ : Eldridge R, Fahn S, eds. Advances in Neurology. New York: Raven Press 1976: 375-402 (Dystonia: vol. 14).

85. Redfield J. Stone A. Individual view points of stressful life events. J Consul Clin Psychol 1979; 47: 147-154.

86. Stejskal L, Tomanek Z. Postural laterality in torticollis and torsion dystonia. J Neurol Neurosurg Psychiatry 1981; 44: 1029-1034.

87. Stejskal L. Counterpressure in torticollis. J Neurol Sci 1980; 48: 9 19.

88. Forgach L, Eisen A, Fleetham J, Calne DB. Studies of dystonic torticollis during sleep. Abstract presented at 38th annual meeting, American Academy of Neurology, New Orleans. Neurology.

89. Campbell K. Body and Mind. 1984, Notre-Dame, Indiana: University of Notre-Dame Press.

90. Gelb DJ, Lowenstein DH, Aminoff MJ. Controlled trial of botulinum toxin injections in the treatment of ST Neurology 1989; 39: 80-84.

91. American Psychiatric Association. Diagnostic and Stastistical Manual of Mental Disorders, Third Edition Revised (DSM III R), Washington DC, APA, 1987.

92. Fahn S, Williams DT. Psychogenic dystonia. In: Fahn S, et al, eds. Advances in Neurology. New York: Raven Press, 1988: 431-455 (Dystonia 2: vol. 50).

93. Lal S, Hoyte KE, et al. Neuropharmacological investigation and treatment of ST. In: Poirier LJ, Sourkes TL, Bedard PJ, eds. Advances in Neurology. New York: Raven Press, 1979: 335-351 (The extra-pyramidal system and its disorders: vol. 24)

94. Tanner CM, Goetz CG, Glantz RH, Nausieda PA, Weiner WJ, Klawans WJ. Cholinergic mechanisms in idiopathic partial and segmental dystonias. Ann Neurol 1981; 10: 94.

95. Stahl, SM, Berger PA. Bromocriptine, physostigmine and neurotransmitter mechanisms in the dystonias. Neurology (NY) 1982; 32: 889-892.

96. Lang AE, Sheehy MP, Marsden CD. Acute anticholinergic action in focal dystonia. In: Fahn S, Calne DB, Shoulsoni I, eds. Advances in Neurology: Raven Press, 1983: 193-200 (Experimental therapeutics of movement disorders: vol. 37).

97. Fahn S. High dosage anticholinergic therapy in dystonia. Neurology (Cleveland) 1983; 33: 1255-1261.

98. Tsui JK, Eisen A, Stoessl JA, et al. Double-blind study of botulinum toxin in spasmodic torticollis. Lancet 1986; 2: 245 246.

99. Stell R, Thompson PD, Marsden CD. Botulinum toxin in spasmodic torticollis. J Neurol Neurosurg and Psychiatry 1988; 51: 920923. 